\title{
PENGARUH KEGIATAN MANDIRI MAHASISWA DALAM KULIAH DARING DI ERA PANDEMI COVID-19
}

\author{
"Alfina Aulia Rohmah" \\ Program Studi Psikologi \\ Fakultas Kedokteran Univesitas Lambung Mangkurat \\ E-mail : alfina.rohmah10@gmail.com
}

\begin{abstract}
Abstrak : Pandemi corona virus disease (Covid-19) memaksa lembaga pendidikan melakukan perubahan dalam sistem pembelajaran bahkan kegiatan mahasiswa. Tidak terkecuali di lingkungan Universitas Lambung Mangkurat (ULM) yang mengeluarkan Surat Edaran Rektor ULM tentang penerapan kuliah online (daring) sebagai upaya cegah penyebaran Covid-19, 16 Maret 2020. Keputusan yang membuat civitas akademika ULM tersentak. Kampus ditutup dan kuliah Di Rumah Aja. Perubahan mendadak tersebut tentu mempengaruhi, bahkan mengguncang kegiatan menulis, terutama mahasiswa. Keputusan kampus yang diambil guna keselamatan bersama. Sesuatu yang harus dan wajib dilakukan sebagai upaya penyelamatan, bukan saja warga kampus, tetapi juga keluarga dan masyarakat pada umumnya.
\end{abstract}

kata kunci : Keiatan Mahasiswa,kuliah daring,era pandemi Covid-19

Abstrac : The corona virus disease pandemic (Covid-19) forces educational institutions to make changes in the learning system and even student activities. The University of Lambung Mangkurat (ULM) has also issued a Circular of the ULM Chancellor regarding the application of online lectures as an effort to prevent the spread of Covid-19, March 16, 2020. The decision that made the ULM academic community jolted. The campus was closed and studied at Rumah Aja. The sudden change certainly affected, even shook psychological resilience, especially students. Campus decisions taken for mutual safety. Something that must and must be done as an effort to save not only campus residents, but also families and society in general.

keywords : student activities, online lectures, the Covid-19 pandemic era 


\section{PENDAHULUAN}

Sebagai mahasiswa saya merasakan hal positif dan negatifnya selama mengikuti perkuliahan di rumah saja. Hal ini berkaitan dengan perubahan sisi kebiasaan yang telah saya jalani sebelum WHO memberikan peringatan ke pemerintah global akan bahayanya virus corona. Jadwal mata kuliah yang sudah ditetapkan, ketika kuliah di rumah saja para koti dan dosen pengampu berunding untuk menyesuaikan perkuliahan online. Hal tersebut penting sehingga pembagian waktu tidak menimbulkan akibat kurang baik.

Di penghujung tahun 2019 seluruh dunia digemparkan dengan sebuah penyakit yang muncul di kota Wuhan yang merupakan ibukota Provinsi Hubei, Tiongkok. Penyakit tersebut bersumber dari virus corona, yang kemudian terus mewabah dan menjadi pandemi yang dikenal dengan COVID -19 (Corona Virus Disease).

Penyebaran COVID -19 yang meluas ini di tengah manusia menimbulkan kekhawatiran masyarakat luas. Hal itu dikarenakan COVID -19 jenis baru ini disebut bisa menyebabkan kematian dengan penularan antar manusia melalui tetesan cairan pernapasan tubuh melalui tangan atau permukaan padat.

Tanpa butuh waktu yang lama pandemi ini tersebar sangat cepat hingga hampir tidak ada negara atau wilayah di dunia yang tidak terserang dari virus Corona COVID -19 termasuk Indonesia.

Diawal bulan maret 2020 Presiden Indonesia secara resmi mengumumkan di semua media massa bahwa terdapat pasien 01 dan 02 positif COVID -19 yang merupakan Ibu dan Anak (Harian Kompas.com). Kondisi ini terus berlanjut hingga beberapa kota di Indonesia selanjutnya terdapat pasien positif COVID -19, Pasien Dalam Pengawasan (PDP) dan Orang Dalam pemantauan (ODP). Dengan jumlah yang kian hari terus bertambah.

Dengan kekhawatiran yang begitu besar terhadap keselamatan rakyat Indonesia maka di berlakukan lah Social Distancing yang merupakan upaya untuk membentuk kelompok-kelompok atau perkumpulan, dan menjaga jarak antar manusia minimal satu meter. Sehingga semua aktivitas belajar dan mengajar yang dilakukan dalam kelas dihentikan dan digantikan dengan kegiatan belajar dan mengajar dari rumah dengan menggunakan bantuan internet atau Daring (Dalam Jaringan). Kondisi yang demikian mengaharuskan perkuliahan menggunakan berbagai aplikasi baik via Smart Phone maupun laptop. 
Kemandirian mahasiswa dalam belajar adalah hal penting yang harus dimiliki oleh seluruh mahasiswa peserta kelas. Karena perkuliahan daring sangat terbatas oleh waktu dan ruang. Sehingga dosen tidak dapat memantau langsung satu persatu mahasiswa dalam satu tatap muka perkuliahan hal inilah yang mengharus mahasiswa lebih mandiri dalam memahami materi dan menyelesaikan tugas yang diberikan oleh dosen. Mahasiswa harus aktif mencari sumber referensi lain bilamana masih ada materi yang belum di pahami.

Mahasiswa harus mandiri dalam menyelesaikan tugas karena terbatasnya ruang interaksi dengan sesama teman dan dosen. Di saat matakuliah eksak merupakan hal sulit dipecahkan dan dipahami yang sering terjadi di dalam kelas, namun ketika hal sulit tersebut terjadi dalam perkuliahan daring maka disinilah sikap kemandirian harus dimiliki oleh mahasiswa dalam belajar.

\section{METODE SYSTEMATIC REVIEW}

Seperti pada metodologi penelitian individual, pada prinsipnya penelitian systematic review dimulai dengan membuat protokol penelitian systematic review dan tahap berikutnya melaksanakan penelitian systematic review.

Analog dengan metodologi penelitian secara umum, di mana terdapat metode kuantitatif dan kualitatif, maka dalam systematic review juga terdapat metode kuantitatif dan metode kualitatif. Metode kuantitatif systematic review adalah digunakan untuk mensintesis hasil-hasil penelitian dengan pendekatan kuantitatif. Misalnya, Randomized Control Trials (RCT), Cohort Study, CaseControl Study, atau studi prevalensi. Pendekatan statistik dalam melakukan sintesis hasil penelitian kuantitatif ini disebut dengan teknik melakukan agregasi data untuk mendapatkan hubungan sebab akibat antara faktor risiko atau perlakuan dengan suatu efek (outcome) (Perry \&Hammond, 2002).

Sementara itu, pendekatan kualitatif dalam systematic review digunakan untuk mensintesis (merangkum) hasil-hasil penelitian yang bersifat deskriptif kualitatif. Metode mensintesis (merangkum) hasil-hasil penelitian kualitatif ini disebut dengan teknik melakukan integrasi data untuk mendapatkan teori maupun konsep baru atau tingkatan pemahaman yang lebih mendalam dan menyeluruh (Perry \&Hammond, 2002). 


\section{META-ANALISIS SEBAGAI METODE SYSTEMATIC REVIEW KUANTITATIF}

Karena meta-analisis adalah metode mengkombinasikan hasil penelitian kuantitatif secara statistik (secara kuantitatif) maka langkah-langkah dalam melakukan meta-analisis adalah sama dengan langkah-langkah melakukan systematic review secara umum. Langkah-langkah tersebut adalah sebagai berikut (Perry \& Hammond, 2002):

1) Identifikasi pertanyaan penelitian (pertanyaan penelitian meta-analisis)

2) Mengembangkan protokol penelitian metaanalisis

3) Menetapkan lokasi data-base hasil penelitian sebagai wilayah pencarian (misalnya MEDLINE,PubMed)

4) Seleksi hasil-hasil penelitian yang relevan

5) Pilih hasil-hasil penelitian yang berkualitas

6) Ekstraksi data dari studi individual

7) Sintesis hasil-hasil penelitian dengan metode meta-analisis (funnel plot dan forest plot).

8) Penyajian hasil penelitian dalam laporan penelitian hasil meta-analisis

\section{HASIL DAN PEMBAHASAN}

Sebagaimana telah disindir di depan bahwa metaanalisis adalah teknik statistik untuk mengkombinasikan Systematic Review sebagai Metode Penelitian (Siswanto) temuan dari beberapa hasil penelitian terdahulu. Meta-analisis biasanya digunakan untuk menilai efektivitas intervensi klinis dengan mengkombinasikan beberapa hasil penelitian randomized control trials (RCT). Maka dari itu, meta-analisis merupakan pondasi (tulang punggung) dalam kedokteran berbasis fakta(evidence based medicine).

Sehingga kita mendapatkan hasil mengenai Pengaruh Kegiatan Mandiri Mahasiswa dalam Kuliah Daring di ERA Pandemi COVID-19 dan dalam mengutip jurnal buku menulis COVID-19 yang disunting Ersis Warmansya Abbas dan Neka Eriyani yaitu, MAHASISWA merupakan satu diantara aset terbesar bangsa dan negara yang menentukan kemajuan dan kehebatan Indonesia di masa depan. Mahasiswa adalah anak-anak bangsa yang sedang mempersiapkan dirinya, untuk dirinya dan bangsanya, pada bidang keilmuan tertentu yang menjadikan dirinya menyandang profesi sesuai bidang keilmuannya alias profesional. Menurut Kamus Besar Bahasa Indonesia (KBBI) mahasiswa adalah seseorang yang belajar di perguruan tinggi, di dalam struktur pendidikan di Indonesia mahasiswa memegang status pendidikan tertinggi diantara yang lain. 
Mahasiswa belajar menggunakan fasilitas-fasilitas yang telah disediakan kampus, dan karena itu, sesuai visi dan misi kampus, mahasiswa dipersiapkan untuk melakukan perubahan ke arah lebih baik.(Nining Fajaryanti,menyahabati covid-19).

Kuliah online menjadi ajang mahasiswa malas, curang, hingga banyak pemikiran lainnya. Pemikiran tersebut tidak sepenuhnya keliru. Dalam ilmu sosial kita mengenal individual differences. Mari kita hargai fakta, namun bukan berarti menjadi dasar untuk menggeneralisasikan sesuatu.

Tidak sedikit dosen yang kecewa dengan sikap mahasiswa yang demikian hingga menerapkan berbagai aturan, mulai dari pengisian daftar hadir dalam banyak sesi hingga kewajiban mengaktifkan kamera. Padahal cara demikian tidak sepenuhnya efektif, karena juga memberikan dampak negatif bagi mahasiswa, seperti meningkatnya resiko kecemasan, stres hingga kesulitan fokus.(nor i'anah,lika liku mahsiswa).

Penambahan jumlah orang yang terinfeksi Covid-19 mengakibatkan proses pembelajaran tatap muka dan penutupan rumah ibadah terjadi semakin lama. Perpanjangan keputusan untuk belajar di rumah rupanya tidak serta merta menjadi kebahagiaan mahasiswa karena mereka menganggap akan terjadi libur panjang. Di luar ekspektasi terdapat kekacauan yang mengancam, mahasiswa dituntut untuk memahami materi yang dijelaskan lewat jejaring sosial media.

Banyak mahasiswa mengeluhkan tidak bisanya kuliah tatap muka menjadi alasan mereka sukar untuk memahami palajaran. Dari kalimat-kalimat yang diucapkan mahasiswa dapat dilihat jika Covid-19 tidak saja menyerang fisik penderitanya, lebih jauh dari itu, orang yang bahkan tidak terinfeksi penyakit tersebut ikut merasakan sakitnya mental. Artinya, Covid-19 tidak hanya berdampak kepada kesehatan tubuh, namun juga berdampak terhadap kesehatan mental baik penderitanya atau bahkan yang tidak menderita penyakit tersebut. Guncangan mental semakin parah akibat proses pembelajaran di rumah ketika menjelang Ujian Akhir Semester (UAS).(Pavita Assiva, Guncangan pembelajaran online).

Selain itu, Covid-19, mengajarkan hal lain. Persiapan tidak bisa hanya mengandalkan rencana manusia. Sekejap Tuhan bisa mengubah dunia dan manusia harus tunduk dengan apa yang terjadi. Tidak menggerutu apalagi menyangkal. Bagaimana bisa menyangkal jika memahami bumi milik-Nya. Bisa jadi, Tuhan ingin memperlihatkan kuasaNya. Betapa Dia ingin mengajarkan bahwa bukan lingkungan yang salah, tetapi manusia yang harus sigap beradaptasi. 


\section{KESIMPULAN}

Dan dapat kita ketahui bahwa Pengaruh Kegiatan Mandiri Mahasiswa dalam Kuliah Daring di Era Pandemi Covid-19 memang bukan peristiwa yang dapat diantisipasi sejak jauh hari, sebab terjadi mendadak. Karena itu, janganlah hanya memandang sisi negatifnya, tetapi lihat juga sisi positifnya. Sisi negatifnya sebagai pembelajaran tanpa memaknai sebagai kesulitan. Sebagai manusia khususnya mahasiswa, kita melakukan introspeksi, kenapa wabah ini sampai terjadi dan tabah dengan berusaha sekuat mungkin mengatasi. Tidak ada kejadian yang sia-sia. Dan tentu dari hal ini kita dapat melihat bahwa hal tersebut sangat berpengaruh terhadap Kegiatan Mandiri Mahasiswa dalam Kuliah Daring di Era Pandemi Covid-19. 


\section{DAFTAR PUSTAKA}

Abbas, E. W. (2014). Pendidikan Karakter.

Subiyakto, B., \& Mutiani, M. (2019). Internalisasi nilai pendidikan melalui aktivitas masyarakat sebagai sumber belajar ilmu pengetahuan sosial. Khazanah: Jurnal Studi Islam dan Humaniora, 17(1), 137-166.

Abbas, E. W., \& Erlyani, N. (2020). Menulis di Kala Badai Covid-19.

WARMANSYAH ABBAS, E. R. S. I. S. (2020). Menulis di Era Covid-19:

Memanage Trauma Psikologis Menghindari Psikosomatis. Menulis di Era Covid19: Memanage Trauma Psikologis Menghindari Psikosomatis.

Wahyuni, R., Mayangsari, M. D., \& Fauzia, R. (2017). Hubungan kecerdasan spiritual dengan perilaku prososial pada perawat di rumah sakit islam banjarmasin. Jurnal Ecopsy, 3(3).

Aridarmaputri, G. S., Akbar, S. N., \& Yuniarrahmah, E. (2016). Pengaruh jejaring sosial terhadap kebutuhan afiliasi remaja di program Studi Psikologi Fakultas Kedokteran Universitas Lambung Mangkurat. Jurnal Ecopsy, 3(1).

Rachmah, D. N., Mayangsari, M. D., \& Akbar, S. N. (2015). Motivasi belajar sebagai mediator hubungan kecerdasan adversitas dan prokrastinasi akademik pada mahasiswa yang aktif berorganisasi. Jurnal Cakrawala Pendidikan, 34(2).

Aridarmaputri, G. S., Akbar, S. N., \& Yuniarrahmah, E. (2016). Pengaruh jejaring sosial terhadap kebutuhan afiliasi remaja di program Studi Psikologi Fakultas Kedokteran Universitas Lambung Mangkurat. Jurnal Ecopsy, 3(1).

Afnan, A., Fauzia, R., \& Tanau, M. U. (2020). HUBUNGAN EFIKASI DIRI DENGAN STRESS PADA MAHASISWA YANG BERADA DALAM FASE QUARTER LIFE CRISIS. Jurnal Kognisia: Jurnal Mahasiswa Psikologi Online, 3(1), 23-29.

Amini, M., Mayangsari, M. D., \& Zwagery, R. V. (2020). Hubungan antara Kemandirian Belajar dengan Komitmen Tugas pada Mahasiswa Program Studi Psikologi. Jurnal Kognisia: Jurnal Mahasiswa Psikologi Online, 2(2), 149-152. 